\title{
GIS-based modeling of runoff source areas and pathways
}

\section{Nikolaus J. Kuhn, Basel, Honglei Zhu, Worcester}

\section{Introduction}

In large parts of the world, frequency of rainfall events with extreme intensity and duration are likely to increase in the $21^{\text {st }}$ century (INTERGOVERNMENTAL Panel on Climate Change, IPCC, 2007). Such change in rainfall characteristics represents a particular problem for modeling runoff, erosion and off-site water pollution because they often cause a non-linear reaction within fields, along hillslopes or small catchments, which will be referred to here as Hydrologic Response Units (HRUs) (DunNe \& AUBrY 1986). The runoff generating area increases with amount and intensity of rainfall, or both, and a larger part of a watershed becomes connected to the valley channel (DUNne \& BLACK 1970). Conventional rainfall-runoff modeling, based on a relationship between rainfall and response unit outlet data, does not integrate these changes in HRU internal functioning (BEVEN \& BINLEY 1992). Climate and land use change will cause a quasi-permanent change of the relevant hydrologic properties and dominating processes in many HRUs in the $21^{\text {st }}$ century (KUHN 2006). This condition of transition exacerbates the problems associated with the use of rainfallrunoff models, especially those relying on calibration using data sets collected under current or past climate and land use. Planning and management of the impact of Environmental Change therefore rely increasingly on so called Reduced Complexity Models (RCMs), developed to address a specific issue associated with Environmental Change (Schulz \& Beven 2003; VAN Oost et al. 2004). However, RCMs still have to rely on empirical relationships based on past or present rainfall-runoff observation. Their application to future conditions therefore may constitute an extrapolation beyond the limits of the data set and may therefore often be restricted to situations where the reaction of HRUs to environmental change is known.

The systematic assessment of the risks associated with the impact of climate and land use change on runoff generation within HRUs offers an alternative to rainfall-runoff models (e.g. AGNEW et al. 2006). Instead of focusing on the prediction of discharge at a given catchment outlet point, the changes in rainfall-surface interaction, runoff generation and routing can be examined on a hillslope scale for different rainfall and land use scenarios. Conceptually, this approach is based on upscaling point data of infiltration capacity and the routing of runoff using a digital elevation model (DEM).
Unlike outlet-based runoff modeling, the need for parameterization of the catchment is kept to a minimum. GIS-based runoff modeling and topography analysis provides the possibility of assessing the risks of changing HRU behavior by examining the spatial patterns of runoff generation and runoff routing within HRUs.

The objective of the work presented in this paper was to design and implement a module into the IDRISI GIS package for calculating runoff amount and routing for single or multiple rainfall events on a hillslope and small catchment scale. The new RUNOFF tool is raster-based and uses topographic and hydrological parameters represented by different layers to calculate values for a spatially distributed output layer of surface runoff. The underlying hydrologic model and the procedures followed for the identification of runoff pathways from the DEM, and a case study examining the risks of runoff generation on grassland from the Eifel region of Germany are presented.

\section{Hydrologic model in RUNOFF}

In this study, raster layers were used both to provide the input parameters and to represent the results. The basic hydrologic model for calculating surface runoff during a rainfall event used here is:

$Q=P-I$

$Q \quad$ Runoff during event

$P \quad$ Rainfall during event

I Infiltration during event

Equation 1

Infiltration was divided into two components: the final infiltration rate and absorption. Absorption includes all the water which is either retained by the surface or infiltrates at a rate higher than the final infiltration rate (Figure 1). The simplicity of the model limits its application to events where surface runoff dominates. Furthermore, the duration of the event has to be sufficiently long so that the entire runoff wave can reach the HRU outlet. The model was transferred into a raster GIS environment with the following input layers (see also Figure 2):

1. A DEM, which defines a rectangular region.

2. A mask file that defines the field or slope section of interest within the rectangular region of the DEM.

3. Rainfall intensity layer where a value of a pixel in the layer gives the rainfall intensity at that location.

4. Rainfall duration layer where a value of a pixel in the layer defines the duration of a rainfall event. 


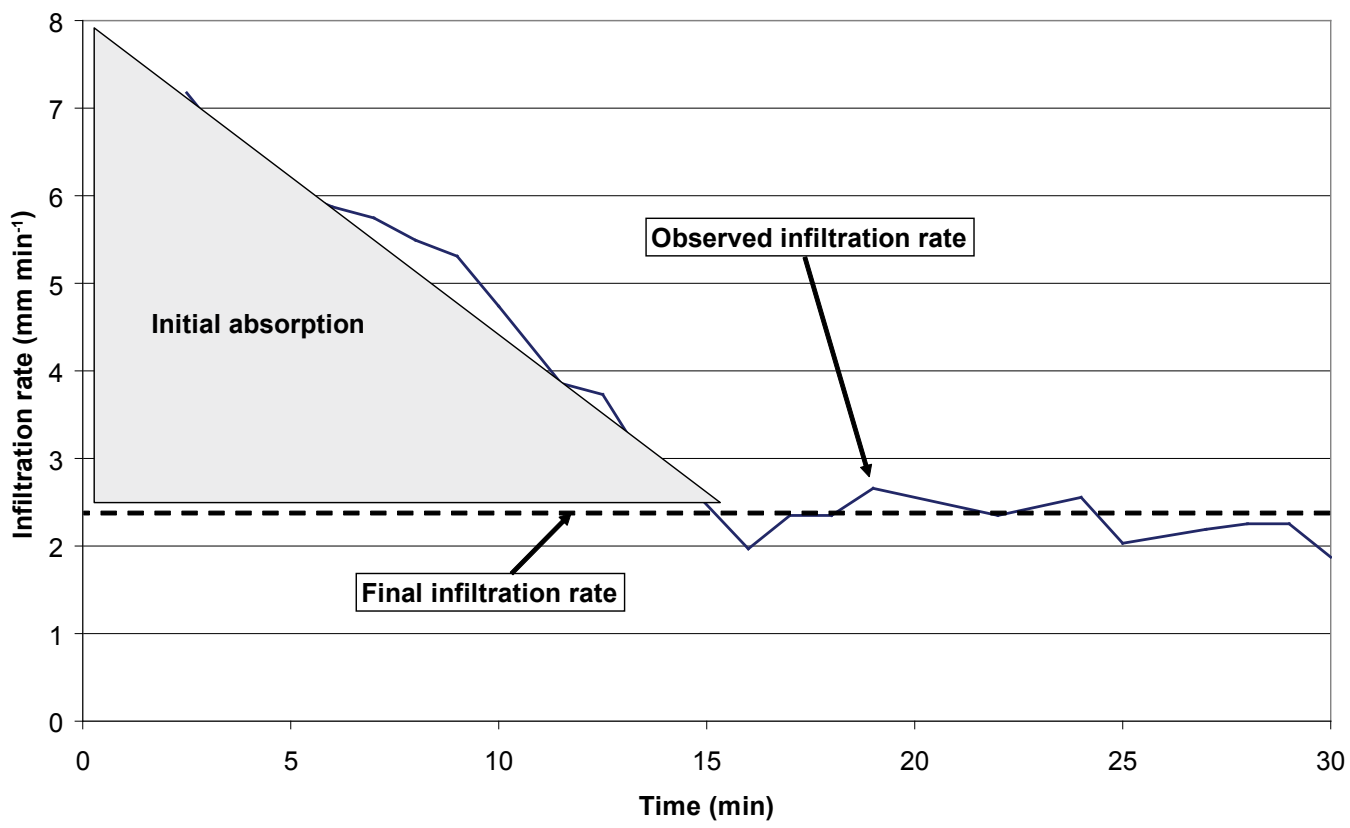

Fig. 1: Estimation of initial absorption and infiltration rate for RUNOFF

Schätzung der anfänglichen Absorptionsmenge und Infiltrationsrate für RUNOFF

Estimation des taux d'absorption et d'infiltration initiaux pour RUNOFF

5. Initial absorption layer which gives the absorption to be fulfilled before runoff may occur.

6. Infiltration layer which describes the final infiltration rate of the pixel.

Using the above parameters as input, the hydrological status of a pixel for a rainfall event can be defined as in equation 2:

$Q=R * T-A-I * T$

$Q \quad$ Runoff during event

$R \quad$ Rainfall intensity during event

$T \quad$ Duration of event

A Absorption during event

I Final infiltration rate during event

Equation 2 shows that a pixel may have one of the three characteristics:

1. Q > 0: the pixel generates surface flow, thus it contributes to the surface runoff.

2. $Q=0$ : the pixel does not generate surface flow and does not take surface flow from its neighbors either.

3. $\mathrm{Q}<0$ : the pixel may act as a runoff sink if it receives runoff from neighboring pixels.

\section{Runoff routing in RUNOFF}

RUNOFF applies a single flow simplification based on Jenson and Domingue (1988). A pixel has eight neighboring pixels to interact with to form runoff, four of them are connected horizontally and vertically, and four others diagonally (Figure 2). Assuming that all pitfalls in a DEM have been removed, a pixel may receive runoff from up to seven of its eight neighbors.

Equation 2 These neighbors must be upper neighbors with elevation values not less than that of the receiving pixel. A pixel can only contribute runoff to one of its neighbors, which is either lower or equal in elevation. Accounting for all possible scenarios for a pixel, the net amount of runoff a pixel carries to its lower neighbor pixel is given in equation 3 :

$Q_{x}=\max \left(Q_{0}+Q_{u}, 0\right)$

Equation 3

Where $\mathrm{Q}_{\mathrm{u}}$ is the runoff from adjacent upper pixels, $\mathrm{Q}_{0}$ is obtained using equation 2 , and $Q_{x}$ is the runoff the current pixel passes on to its lower neighbor. The max operator limits $\mathrm{Q}_{\mathrm{x}}$ to a non-negative value when $\mathrm{Q}_{0}+$ $\mathrm{Q}_{\mathrm{u}}<0$. The interpretation of $\mathrm{Q}_{\mathrm{x}}$ is that a pixel may contribute runoff to a lower neighbor; it may take some or all of the runoff it receives from its upper neighbors, 


\begin{tabular}{|l|l|l|l|l|}
\hline 100 & 100 & 100 & 100 & 100 \\
\hline 100 & 100 & 95 & 95 & 100 \\
\hline 100 & 95 & 90 & 85 & 100 \\
\hline 100 & 95 & 90 & 80 & 100 \\
\hline 100 & 100 & 100 & 100 & 75 \\
\hline
\end{tabular}

A small digital elevation model (DEM) with the region of interest grayed

\begin{tabular}{|l|l|l|}
\hline 1.10 & 1.10 & 1.15 \\
\hline 8.9 & 1.10 & 1.15 \\
\hline 1.10 & .90 & .80 \\
\hline
\end{tabular}

Rainfall intensity $\left(\mathrm{mm} \mathrm{min}^{-1}\right)$

\begin{tabular}{|c|c|c|}
\hline 8 & 7 & 5 \\
\hline 8 & 6 & 5 \\
\hline 7 & 4 & 4 \\
\hline
\end{tabular}

Initial absorption $\left(\mathrm{mm} \mathrm{min} \mathrm{m}^{-1}\right)$

\begin{tabular}{|l|l|l|}
\hline 100 & 100 & 100 \\
\hline 100 & 100 & 100 \\
\hline 100 & 100 & 100 \\
\hline
\end{tabular}

Duration (minute)

\begin{tabular}{|c|c|c|}
\hline 10 & 20 & 15 \\
\hline 10 & 15 & 15 \\
\hline 20 & 20 & 25 \\
\hline
\end{tabular}

Total infiltration (mm)

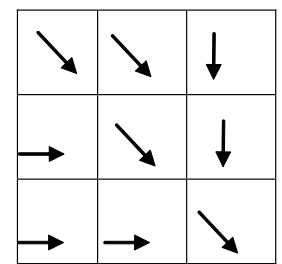

Derived flow direction layer

\begin{tabular}{|l|l|l|}
\hline 110 & 110 & 115 \\
\hline 89 & 110 & 115 \\
\hline 110 & 90 & 80 \\
\hline
\end{tabular}

Total rainfall received $(\mathrm{mm})$

\begin{tabular}{|c|c|c|}
\hline 92 & 83 & 95 \\
\hline 71 & 89 & 95 \\
\hline 83 & 66 & 51 \\
\hline
\end{tabular}

Remaining rainfall (mm)

\begin{tabular}{|l|l|l|}
\hline 0.1 & 0.2 & 0.15 \\
\hline 0.1 & 0.15 & 0.15 \\
\hline 0.2 & 0.2 & 0.25 \\
\hline
\end{tabular}

Infiltration rate $\left(\mathrm{mm} \mathrm{min} \mathrm{m}^{-1}\right)$

\begin{tabular}{|c|c|c|}
\hline 92 & 83 & 95 \\
\hline 71 & 252 & 273 \\
\hline 83 & 149 & 725 \\
\hline
\end{tabular}

Calculated runoff (mm)

Fig. 2: Simple example of runoff calculation and flow path extraction used in RUNOFF

Beispielberechnung des Oberflächenabflusses und der Bestimmung der Fliesswege mit Hilfe von RUNOFF Exemple de calcul de ruissellement et de flux utilisé par RUNOFF

but it cannot take any runoff from its lower neighbors.

\subsection{Removal of pitfalls}

The process of accumulating runoff assumes that a surface flow continues moving downward into one of its eight neighbors before it flows out of the study area or totally infiltrates if there is no more runoff. Within a watershed, any surface flow should get to the outlet of the watershed if it is not infiltrated on its pathway. A pitfall in a DEM is a local elevation minimum with no lower neighbors which prevents runoff from continuing flowing into any of its neighbors. Such pitfalls cause erroneous runoff results because they act as unnatural sinks in the model. They therefore have to be removed from the DEM before runoff is calculated.
There are three steps involved in this pitfall removal process. The first step is to identify pitfalls. Pixels located at the pitfalls are identified as those with elevation values at a local minima. The second step is to identify an optimal drainage path connecting a pitfall to its outlet, which would be a pixel on its path and with a lower elevation value than the pitfall pixel. A priority-first search algorithm (SEDGEWICK 1992) is implemented to identify the path. It starts from the pitfall pixel and searches for an optimum path that would connect it to its outlet. Two criteria are employed in the priority-first search algorithm in finding the path. The first criterion is that the next pixel on the path should have the smallest net elevation gain from the previous pixel if moving upwards, or largest elevation drop when moving downwards. The second criterion 


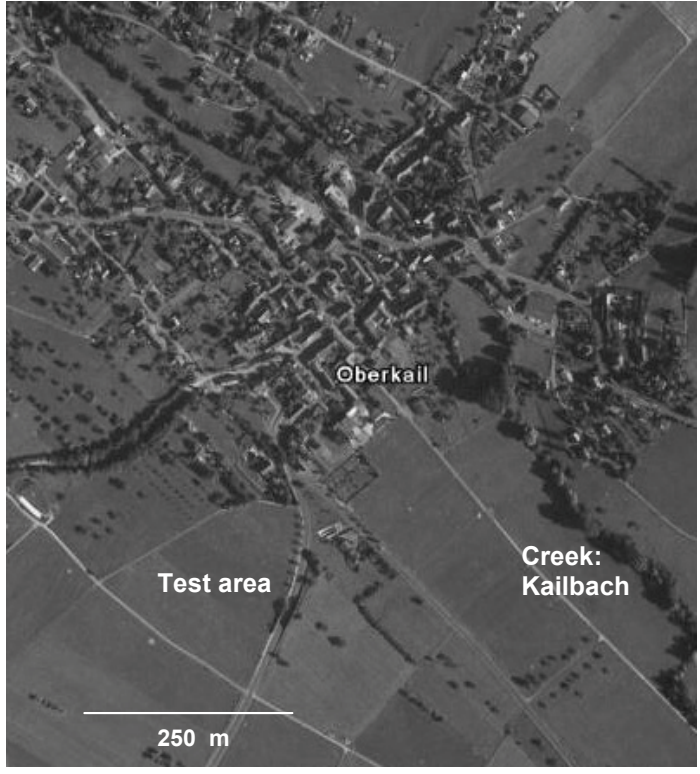

Fig. 3: Town of Oberkail in Germany with grassland test area $\left(50^{\circ} 02^{`} \mathrm{~N}, 6^{\circ} 40^{\circ} 40^{\prime \prime} \mathrm{E}\right)$

Der Ort Oberkail, Deutschland, mit dem GraslandTestgebiet $\left(50^{\circ} 02{ }^{`} \mathrm{~N}, 6^{\circ} 40^{`} 40^{\prime} \mathrm{E}\right)$

La ville d'Oberkail et la zone d'étude herbeuse $\left(50^{\circ} 02^{`} \mathrm{~N}\right.$, 6 $\left.400^{`} 40^{\prime \prime} E\right)$

Photo: Google Earth, August 2007 (modified)

is that when there is a tie according to the first criterion, the path with a shorter distance has a higher priority. Finally, the third step is to lower the elevation of all pixels along the optimum drainage path to create a consistent downward gradient between the original pit pixel and the outlet pixel. When the pitfall removal process is completed, the resulting surface image ensures that any cell in the image can follow along a path to the edge of the image. A path consists of cells that are adjacent horizontally, vertically, or diagonally in the raster grid and decrease monotonically in value.

\subsection{Identification of flow pathways}

Flow pathways are derived from the pitfall-clear surface image using the approach described by JENSON and Domingue (1988). The example in Figure 2 shows the flow direction for a $3 \times 3$ pixel surface. One of the eight neighboring pixels is identified as the lower neighbor to flow into. Using the flow direction image, any pixel in the test area can find its path to get to the boundary of the study area. If the study area is a complete watershed, then all of the runoff should go through the outlet of the watershed. The outlet is located on the boundary of a watershed and it should have the lowest elevation value of the watershed.

\subsection{Runoff calculation}

Every pixel in the study area is examined in a strict order. Whether a pixel is ready to be processed depends on all of its upper neighbors. If all of its upper neighboring pixels have been processed, then the pixel's runoff value can be calculated using equation 2 and 3. Naturally, the starting pixels for a runoff process are those located either at the top of hills or ridges. A simplified example is illustrated in Figure 2 to demonstrate the methodology.

\section{Potential impact of land use and climate change on runoff from grassland in the Eifel region, Germany}

\subsection{Study area}

The new RUNOFF module was tested using data from a 3.45 ha grazing area near the town of Oberkail in the Eifel region of Germany (Figure 3). The soil in the area is a silty Luvisol which has developed on upland plateaus formed by Triasic Muschelkalk (WERLE 1978). The area was chosen because it represents a typical upland part (350 to $400 \mathrm{~m}$ a.s.l.) of first order catchments contributing to the Mosel river, which has one of the highest flood frequencies of all rivers in Germany. The study area was split into seven units after a farmland consolidation scheme in the 1960s. Today, all seven units have been amalgamated and are used by one farmer as meadow for silage production and grazing. The test area is surrounded by paved roads, which lie lower than the field and thus collect all the runoff from the field and provide a rapid connection to drainage systems and the creek (Kailbach) in the main valley. Understanding the interaction between surface and rainfall is of critical importance for assessing flood risk in the future. Currently, annual rainfall averages 920 millimeters per year. Maximum daily rainfall reaches $60 \mathrm{~mm}$, and the maximum amount of event rainfall, i.e. during consecutive days with rain, is up to $220 \mathrm{~mm}$ in 10 days. Rainfall is rarely continuous over more than a few hours, however, information on rainfall intensity is scarce. The highest rainfall intensities are associated with convective thunderstorms. Local observations showed that amounts of up to $45 \mathrm{~mm}$ rainfall can fall in 30 minutes (May 13 $3^{\text {th }} 1993$, pers. comm. D. Gerten), and peak intensities of $1.6 \mathrm{~mm}$ per minute (17.6.2005, N.J. KuHN, unpublished data) have been observed. These intensities are sufficient to overcome the infiltration capacity of intensively used grassland, which in current planning is generally considered as not-contributing to surface runoff during summer thunderstorms (MANiAK 2005). However, the magnitude and frequency of high intensity rainfall events will increase in the next 100 years (INTERGOV- 


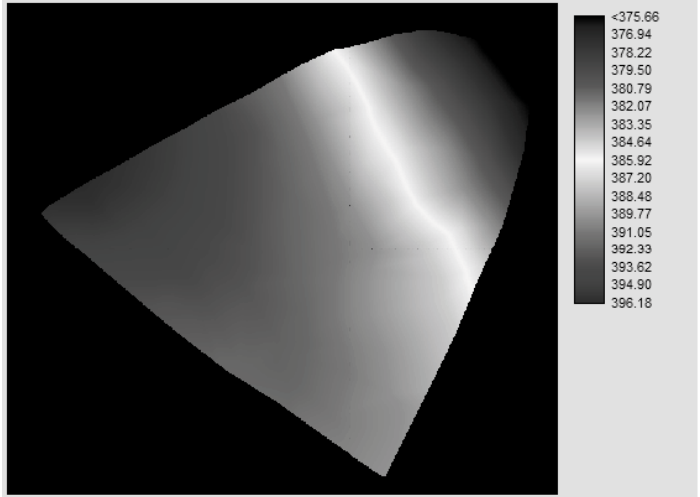

Fig.4:Masked DEM (digital elevation model) used for runoff calculations; legend denotes elevation above sea level. Digitales Höhenmodell (DHM) zur Berechnung des Oberflächenabflusses; die Legende zeigt die Höhe über Meer. Modèle numérique de terrain utilisé pour le calcul du ruissellement; la légende indique l'altitude au-dessus du niveau de la mer.

ernmental Panel on Climate Change, IPCC, 2007). Furthermore, consolidation of farmland and the trend towards high-intensity fodder production for diary farming bear the risk of reducing infiltration capacity through soil compaction (HoRN et al. 1995) and removal of barriers between land use units. Therefore, the probability of surface runoff during summer thundershowers is likely to increase. The results reported here aim at illustrating the methodological approach on one field, but could easily be expanded to a larger area, for example all fields connected to roads leading into the town of Oberkail.

\subsection{DEM, infiltration and initial absorption}

The new RUNOFF module offers the possibility to assess the risk of surface runoff associated with extreme rainfall events and land use change. A DEM of the field near Oberkail was produced by digitizing elevation from the 1:5000 orthophoto. Areas outside the test field were masked and excluded from the analysis (Figure 4). Elevation of a rim of one pixel width surrounding the field was reduced by $1 \mathrm{~m}$ to ensure that the effect of the lower lying roads on runoff routing was fully represented in the DEM. The roads did not receive any rainfall, their infiltration was set to 0 and absorption to $1 \mathrm{~mm}$. Infiltration data collected along the grass field were used to produce infiltration and absorption layers for the RUNOFF module. Infiltration was measured along a five-point transect across the test field, with three replicates along a $100 \mathrm{~m}$ line on each point. Tests were conducted using a spray nozzle mounted $2 \mathrm{~m}$ above the soil surface, supplied from a
500 liter pump barrel hooked to a tractor. The rainfall had an intensity of $5 \mathrm{~mm}$ per minute and covered a circle of $2.5 \mathrm{~m}$ diameter. In the center of the wetted circle, a 0.5 by 0.5 meter plot was separated and runoff was collected in a trough. Infiltration tests were conducted on field fresh soil moisture conditions to ensure similar effects of soil moisture on infiltration capacity. The timing of the infiltration tests simulates a scenario where a high intensity thunder shower follows a short wet spell, which is a typical weather pattern caused by mid-latitude cyclones during the summer. Soil moisture can be easily corrected for differences relative to field capacity based on preceding weather conditions. Based on these tests, infiltration curves were calculated for each site. Final infiltration was relatively uniform across the test field $\left(1.5 \mathrm{~mm} \mathrm{~min}^{-1}\right)$, while absorption was lowest at the steeper mid-slope section $(6 \mathrm{~mm})$ in comparison to the upland plateau $(12 \mathrm{~mm})$ and the flat lower section of the testfield $(8 \mathrm{~mm})$.

\subsection{Rainfall scenarios}

The aims of the simulations conducted with RUNOFF were twofold. First, to identify how total runoff from the grassland would increase with rainfall intensity and reduced infiltration and absorption, and second, how source area distribution and connectivity within the test field would change for the simulated scenarios. The peak event magnitudes and intensities observed between 1988 and 2003 were used as a baseline rainfall event, set for a duration of 30 minutes at an intensity of $1.5 \mathrm{~mm}$ per minute. These values correspond to both the highest observed amount of rainfall in 30 minutes and the peak rainfall intensity during thundershowers. From this baseline scenario, rainfall intensity, infiltration, and absorption were modified to assess the sensitivity of runoff to future climatic conditions and soil compaction. In addition, runoff during three consecutive ten-minute intervals with different rainfall intensity and gradually filling absorption was tested. The full details of the simulated scenarios are given in Table 1 .

Total runoff from the test area was calculated from the accumulated millimeter of rainfall value of the lowest lying pixel. The value of the pixel was converted into liters by multiplying the accumulated millimeters of rainfall by the size of the pixel. The size of a pixel was determined by dividing the size of the field by the number of pixels in the field. One pixel had an area of $0.16 \mathrm{~m}^{2}$. Accordingly, a millimeter of rainfall on a pixel corresponds to 0.16 liters. The amount of runoff that would be generated on the roads during the simulated events was used as a reference for the significance of the grassland contribution to surface runoff.

\subsection{Results of rainfall-runoff modeling}

Results of the simulation are summarized in Table 2. The highest runoff contribution from the test 


\begin{tabular}{|c|c|c|c|c|c|}
\hline Scenario & Description & $\begin{array}{c}\text { Duration } \\
\text { (min) }\end{array}$ & 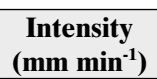 & $\begin{array}{l}\text { Infiltration } \\
\left(\mathrm{mm} \mathrm{min}^{-1}\right)\end{array}$ & $\begin{array}{l}\text { Absorption } \\
\text { (mm)* }\end{array}$ \\
\hline Baseline & Based on observations from 1988 to 2002 & 30 & 1.5 & 1.5 & 10.3 \\
\hline \multirow[t]{3}{*}{ A1 to A3 } & \multirow{3}{*}{$\begin{array}{l}\text { Stepwise increase of rainfall intensity to } 3 \\
\text { mm per minute, simulating more extreme } \\
\text { rainstorm }\end{array}$} & 25 & 1.8 & 1.5 & 10.3 \\
\hline & & 20 & 2.25 & 1.5 & 10.3 \\
\hline & & 15 & 3 & 1.5 & 10.3 \\
\hline \multirow[t]{3}{*}{$\mathrm{B} 1$ to $\mathrm{B} 3$} & \multirow{3}{*}{$\begin{array}{l}\text { Stepwise reduction of infiltration rate to } \\
\text { half of the observed value, simulating } \\
\text { effects of soil compaction on infiltration }\end{array}$} & 30 & 1.5 & 1.25 & 10.3 \\
\hline & & 30 & 1.5 & 1 & 10.3 \\
\hline & & 30 & 1.5 & 0.75 & 10.3 \\
\hline \multirow[t]{4}{*}{$\mathrm{C} 1$ to $\mathrm{C} 4$} & \multirow{4}{*}{$\begin{array}{l}\text { Stepwise reduction of infiltration to half } \\
\text { of the observed value at } 50 \% \text { of observed } \\
\text { absorption, simulating effects of soil } \\
\text { compaction on absorption and infiltration }\end{array}$} & 30 & 1.5 & 1.5 & 5.1 \\
\hline & & 30 & 1.5 & 1.25 & 5.1 \\
\hline & & 30 & 1.5 & 1 & 5.1 \\
\hline & & 30 & 1.5 & 0.75 & 5.1 \\
\hline D1 & $\begin{array}{l}\text { Ten-minute, } 2.5 \mathrm{~mm} \mathrm{~min}^{-1} \text { shower at } \\
\text { beginning of } 30 \text { minute storm }\end{array}$ & 10 & 2.5 & 1.5 & 10.3 \\
\hline D2 & $\begin{array}{l}\text { Ten-minute } 2.5 \mathrm{~mm} \mathrm{~min}^{-1} \text { shower } \\
\text { following } 10 \text { minutes of } 1.5 \mathrm{~mm} \mathrm{~min}^{-1} \\
\text { rainfall }\end{array}$ & 10 & 2.5 & 1.5 & 0 \\
\hline D3 & $\begin{array}{l}\text { Ten-minute } 2.5 \mathrm{~mm} \mathrm{~min}^{-1} \text { intensity shower } \\
\text { following } 20 \text { minutes of } 1.5 \mathrm{~mm} \mathrm{~min}^{-1} \\
\text { rainfall }\end{array}$ & 10 & 2.5 & 1.5 & 0 \\
\hline
\end{tabular}

*Area-weighted average

Tab. 1: Simulated rainfall, infiltration and absorption scenarios Simulierte Niederschlags-, Infiltrations- und Absorptionsszenarien Scénarios simulés de pluviosité, d'infiltration et d'absorption

\begin{tabular}{|c|c|c|c|c|c|}
\hline Scenario & Q (l) & $\begin{array}{c}\text { Road runoff } \\
\text { (l)* }\end{array}$ & Ratio field/road & Total Q (I) & Runoff coefficient \\
\hline Baseline & 0 & 220500 & 0 & 220500 & 0.15 \\
\hline A1 & 3496 & 220500 & 0.02 & 223996 & 0.16 \\
\hline A2 & 167214 & 220500 & 0.76 & 387714 & 0.27 \\
\hline A3 & 433446 & 220500 & 1.97 & 653946 & 0.45 \\
\hline B1 & 3496 & 220500 & 0.02 & 223996 & 0.16 \\
\hline B2 & 167214 & 220500 & 0.76 & 387714 & 0.27 \\
\hline B3 & 433446 & 220500 & 1.97 & 653946 & 0.45 \\
\hline C1 & 0 & 220500 & 0.00 & 220500 & 0.15 \\
\hline C2 & 83607 & 220500 & 0.38 & 304107 & 0.21 \\
\hline C3 & 349839 & 220500 & 1.59 & 570339 & 0.40 \\
\hline C4 & 616071 & 220500 & 2.79 & 836571 & 0.58 \\
\hline D1 & 10506 & 122500 & 0.09 & 133006 & 0.17 \\
\hline D2 & 354976 & 122500 & 2.90 & 477476 & 0.60 \\
\hline D3 & 354976 & 122500 & 2.90 & 477476 & 0.60 \\
\hline
\end{tabular}

*calculated based on a road surface area of $4900 \mathrm{~m}^{2}$, duration of shower and rainfall intensity

Tab. 2: Results of rainfall-runoff simulation Ergebnisse der Niederschlags- und Oberfächenabflusssimulation Résultats des simulations du ruissellement lié à la pluviométrie 

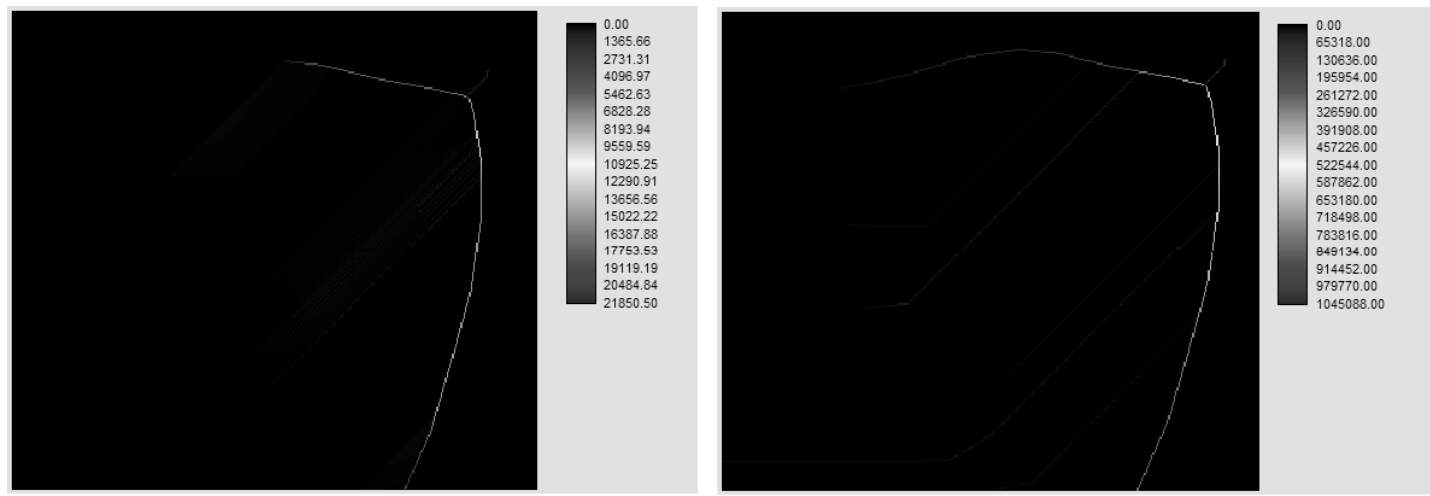

Fig. 5: Runoff in the lower slope section for scenario A1 (left) and A2 (right). Note that scales for runoff are different.

Oberflächenabfluss des unteren Teils des Hanges für die Szenarien A1 (links) und A2 (rechts). Die Masseinteilungen des Oberflächenabflusses sind unterschiedlich.

Ruissellement dans la section inférieure de la pente pour les scénarios A1 (gauche) et A2 (droite). A noter que les échelles des ruissellements sont différentes.

area occurred for scenario $\mathrm{C} 4$, when infiltration and absorption had been reduced to $50 \%$ of their observed values. The greatest increase in runoff coefficient and relative importance of grassland contribution to total runoff developed during scenarios D2 and D3 when preceding rainfall had saturated the absorption capacity of the soil. Overall, contributions from the grassland exceeded road runoff for scenario A3 (double rainfall intensity), B3 (50\% infiltration), $\mathrm{C} 3$ and $\mathrm{C} 4$ (reduced absorption and infiltration), and D2 and D3 (saturation of absorption during preceding showers). Overall, it is noteworthy that small changes in infiltration and absorption caused equal or greater increase in runoff than increasing rainfall intensity. While the test field generated up to nearly three times more runoff than the road, the effect was not linearly related to changes in rainfall intensity, infiltration and absorption. For example, increasing rainfall intensity by $20 \%$ between scenarios $\mathrm{A} 1$ and A2 led to a 48-fold increase of runoff. The non-linearity is attributed to the saturation of the absorption layer and effects of the spatial pattern of absorption on runoff generation and continuity. The runoff patterns in the output images explain the non-linearity. For scenario A1, most runoff originates from the steeper middle sections of the slope (Figure 5), while the upper and lower sections do not contribute significantly. A further increase of rainfall intensity (scenario A2) fills up absorption in the lower slope section, effectively reducing infiltration capacity, and now both the upper and lower sections of the slope generate runoff. Calculating runoff using a spatially averaged absorption value confirms the significance of using spatially varying absorption (Table 3 ). For most scenarios, an average absorption value leads to an overestimation of runoff, in particular for the events with only small increase in intensity or decrease of absorption or infiltration. The overestimation is attributed to ignoring the sink in the lower section of the slope. The underestimation for events D2 and D3 (3\%) is caused by a slight difference in the actual surface area of the grass field and the surface area of the masked DEM used by RUNOFF.

\section{Conclusions}

The new RUNOFF module in IDRISI provides an integrated tool for analyzing the risks associated with Hydrologic Response Unit reaction to environmental change. By adding layers for rainfall intensity and duration, the impact of changes in event magnitude of future rainfall on patterns of runoff generation, routing and connectivity within HRUs can be simulated. The results of the study conducted on the Eifel grass field demonstrate the use of RUNOFF. Non-linear responses of runoff are closely related to the spatial pattern of runoff source and sink areas. Runoff on Eifel grassland appears to be more sensitive to a reduction of infiltration and absorption, and thus land management practices, than rainfall intensity. While certainly preliminary, the results demonstrate the use of RUNOFF in risk assessment studies by indicating that the study area appears to be close to becoming a 


\begin{tabular}{|c|c|c|c|}
\hline Scenario & Q (I) & $\begin{array}{c}\text { Q (I) with average } \\
\text { absorption }\end{array}$ & $\begin{array}{c}\text { RUNOFF Q/average } \\
\text { Abs Q }\end{array}$ \\
\hline Baseline & 0 & 0 & 0 \\
\hline A1 & 3496 & 258740 & 0.01 \\
\hline A2 & 167214 & 517490 & 0.32 \\
\hline A3 & 433446 & 776240 & 0.56 \\
\hline B1 & 3496 & 258740 & 0.01 \\
\hline B2 & 167214 & 517490 & 0.32 \\
\hline B3 & 433446 & 776240 & 0.56 \\
\hline C1 & 0 & 0 & 0 \\
\hline C2 & 83607 & 258745 & 0.32 \\
\hline C3 & 349839 & 517495 & 0.68 \\
\hline C4 & 616071 & 776245 & 0.79 \\
\hline D1 & 10506 & 344990 & 0.03 \\
\hline D2 & 354976 & 345000 & 1.03 \\
\hline D3 & 354976 & 345000 & 1.03 \\
\hline
\end{tabular}

Tab. 3: Comparison of runoff using spatially distributed and average runoff Vergleich des Oberflächenabflusses, anhand des räumlich verteilten und mittleren Oberflächenabflusses Comparaison du ruissellement en utilisant le ruissellement spatialement distribué et moyen

significant runoff contributor during extreme rainfall events, especially when soil compaction and increase in rainfall intensity coincide.

The new RUNOFF offers the possibility to use directly measured infiltration data. While any direct measurement provides only a benchmark value for the area it represents, the approach has the benefit of being directly observed, rather than derived indirectly from outlet data and soil and land use information (e.g. United States Department of Agriculture (USDA) curve approach). This has several advantages. First of all, the effects of land management, for example soil conservation practices, can be incorporated directly into the infiltration and absorption layer, rather than being ignored or estimated using empirical approaches. Second, infiltration measurements can be combined with remotely sensed data and further landscape analysis to determine the extent of areas with similar infiltration and absorption (e.g. JENSEN 2007). Embedding a runoff model in a GIS also allows a relatively easy integration of man-made runoff pathways, such as roads, ditches, separating walls and hedges, into the surface DEM. Finally, the link between infiltration test and change in patterns and pathways of runoff generation is much more direct and transparent than for outletdata based runoff models. This is of particular importance when stakeholders have to be informed about the effects of climate and land use change on runoff.
Further studies using RUNOFF will involve studying the effects of changing rainfall characteristics, the reduction of soil storage capacity due to compaction by heavy machinery and inappropriate tillage practices. Special attention will be given to the use of remotely sensed data in combination with infiltration tests. These studies will also allow the separation of climate from land cover/land management change signal in runoff.

\section{References}

Agnew, L.J., Lyon, S., Gérard-Marchant, P., Collins, V.B.,LEMbo,A.J., STEENhuis, T.S. \& M.T. WALTER (2006): Identifying hydrologically sensitive areas: Bridging the gap between science and application. - In: Journal of environmental management 78: 63-76.

Beven, K. \& A. Binley (1992): The future of distributed models. Model calibration and uncertainty prediction. - In: Hydrological processes 6: 279-298.

DunNe, T. \& B.F. Aubry (1986): Evaluation of Horton's theory of sheetwash and rill erosion on the basis of field experiments. - In: Abrahams, A.D. (ed.): Hillslope processes. - Boston, Mass., London: Allen and Unwin: 31-53.

Dunne, T. \& R.D. Black (1970): Partial-area contributions to storm runoff in a small New England watershed. - In: Water resources research 6: 12961311.

GERTEN, D. (2005): Niederschlagsdaten für Oberkail 
1985 bis 1995. - Unpublished data, collected by Dr. Dieter Gerten, Potsdam Institute for Climate Impact Research (PIK), Telegrafenberg A62, D-14473 Potsdam, Germany.

Horn, R., Domzal, H., Slowinska-Jurkiewicz, A. \& C. VAN QUWERKERK (1995): Soil compaction processes and their effects on the structure of arable soils and the environment. - Soil and tillage research 35:23-26. Intergovernmental Panel on Climate Change (IPCC), Solomon, S., Qin, D., Manning, M., Marquis, M., Averyt, K., Tignor, M.M.B., Miller, Jr., H.L. \& Z. CHEN (eds) (2007): Climate change 2007. The physical science basis. - Contribution of Working Group 1 to the Fourth Assessment Report of the Intergovernmental Panel on Climate Change. - Cambridge: Cambridge University Press.

Jensen, J.R. (2007): Remote sensing of the environment. An earth resource perspective. $-2^{\text {nd }}$ edtion, Upper Saddle River, NJ: Pearson Prentice Hall.

Jenson, S. \& J. Domingue (1988): Extracting topographic structure from digital elevation data for geographic information system analysis. - In: Photogrammetric engineering and remote sensing 54, 11: 1593-1600.

Maniak, U. (2005): Hydrologie und Wasserwirtschaft. Eine Einführung für Ingenieure. - Berlin: Springer.

KunN, N.J. (2006): Managing the impact of climate change on the hydrology of the Gallocanta Basin, NESpain. - Accepted by Journal of environmental quality.

Schulz, K. \& K.J. Beven (2003): Data-supported robust parameterisations in land surface - atmosphere flux predictions: towards a top-down approach. - In: Hydrological processes 17: 2259-77.

Sedgewick, R. (1992): Algorithms in C++. - Reading, Mass.: Addison-Wesley Publishing Company.

Van Oost, K., Beuselinck, L., Hairsine, P.B. \& G. Govers (2004): Spatial evaluation of multi-class sediment transport and deposition model. - In: Earth surface processes and landforms 29: 1027-1044.

Werle, O. (1978): Trier und Umgebung. - Sammlung Geographischer Führer 11, Berlin, Stuttgart: Gebrüder Borntraeger.

\section{Abstract: GIS-based modeling of runoff source areas and pathways}

The application of runoff models that rely on calibration to future land use and climate conditions is restricted to situations where the reaction of Hydrologic Response Units to environmental change is known. This limitation and the ensuing uncertainty of model results can be avoided when a risk-based approach to landscape and runoff analysis is taken. GIS-based landscape analysis provides the possibility of assessing the risks associated with non-linear responses of Hydrologic Response Units to changing rainfall and land use. In this paper, a runoff module designed for IDRISI-Andes to calculate runoff amount and routing for single or multiple rainfall events on a hillslope at small catchment scale is presented. The module is raster-based and uses layers with topographic and hydrological parameters to calculate a spatially distributed output layer of surface runoff. Conceptually, the module extrapolates point data of infiltration capacity onto a field or hillslope. A spatially distributed runoff map is calculated based on the addition of layers with rainfall data and the routing of runoff through pathways connecting pixels in a digital elevation model. Unlike outlet-based runoff modeling, the need for parameterization of the catchment is kept to a minimum. The application of the RUNOFF module in a test area in the Eifel region of Germany indicated that runoff from grassland is sensitive to small increases in rainfall intensity and soil compaction. The spatial patterns of infiltration capacity also contribute significantly to the non-linearity of the test area reaction to changing rainfall and soil hydrologic properties.

Keywords: risk assessment, runoff modelling, hillslopes, environmental change, GIS

\section{Résumé: Modélisation de l'origine et du tracé du ruissellement à l'aide d'un SIG}

L'application de modèles de ruissellement fondés sur la calibration des futurs types d'utilisation du sol et sur les conditions climatiques est limitée aux situations où la réaction des Unités de Réponse Hydrologiques (URH) au changement environnemental est connue. Les limites et les imprécisions des résultats du modèle peuvent être évitées en adoptant une analyse du paysage et du ruissellement basée sur le risque. L'analyse par SIG donne la possibilité d'évaluer les risques associés aux réponses non linéaires des URH aux changements de la pluviométrie et de l'usage du sol. Dans cet article, un module de ruissellement adapté à IDRISIAndes est présenté, ce qui permet de calculer le montant et la direction du ruissellement pour un ou plusieurs épisodes de pluie sur un bassin versant ou sur une portion plus réduite. Le module raster utilise des couches contenant des paramètres topographiques et hydrologiques de manière à calculer la distribution spatiale du ruissellement de surface. Conceptuellement, il extrapole les données ponctuelles relatives à la capacité d'infiltration d'un champ ou d'un bassin versant. La carte du ruissellement est alors basée sur l'addition des couches de données de pluviométrie ainsi que sur l'orientation des écoulements à travers des chenaux dans un modèle numérique de terrain. Contrairement à la modélisation du ruissellement basée sur les exutoires, la nécessité de paramétrer la portion de terrain est réduite au minimum. L'application du module RUNOFF sur une zone test de la région de l'Eifel en 
Allemagne indique que le ruissellement sur une prairie est sensible à de faibles augmentations de l'intensité pluviométrique et à la compacité du sol. Les schémas spatiaux relatifs à la capacité d'infiltration contribuent aussi significativement à la non linéarité des réactions des zones d'essai aux changements de pluviométrie ainsi qu'aux propriétés hydrologiques du sol.

Mots-clés: évaluation du risque, modélisation du ruissellement, versant, changement environnemental, SIG

\section{Zusammenfassung: GIS-basierte Modellierung von Abflussgebieten und Fliesswegen}

Die Anwendung von Oberflächenabflussmodellen, welche sich auf eine Kalibrierung der zukünftigen Landnutzung und Klimabedingungen stützen, sind beschränkt auf Situationen, für welche die Reaktion der Hydrologic Response Units (Hydrologische Reaktionseinheiten) auf eine Veränderung der Umwelteinflüsse bekannt sind. Diese Einschränkung und die sich daraus ergebende Unsicherheit der Modellresultate können vermieden werden, wenn ein Risiko-basiertes Verfahren zur Landschafts- und Oberflächenabflussanalyse angewandt wird. GIS-basierte Landschaftsanalysen beinhalten die Möglichkeit einer Risikoeinschätzung, verbunden mit nichtlinearen Reaktionen der Hydrologic Response Units auf eine Veränderung des Regenfalls und der Landnutzung. In der vorliegenden Veröffentlichung wird ein für IDRISI-Andes entworfenes Oberflächenabflussmodell vorgestellt, welches eine Berechnung der Summe des Oberflächenabflusses und des Abflussverhaltens für einzelne oder sich wiederholende Regenfälle für einen Hang und ein kleines Einzugsgebiet erlaubt. Das Modell basiert auf Rasterdaten und benutzt Ebenen mit topographischen und hydrologischen Parametern, um eine räumlich verteilte Ebene des Oberflächenabflusses zu erhalten. Aus konzeptioneller Sicht extrapoliert das Modell die
Infiltrationskapazität von gemessenen Datenpunkten auf ein Feld oder einen Hang. Eine räumlich verteilte Abflusskarte wrid berechnet. Diese beruht auf Niederschlagsdaten und der Hochwasserabflussberechnung entlang von Fliesswegen, welche mit Hilfe eines digitalen Höhenmodells berechnet werden. Im Gegensatz zu Oberflächenabflussmodellen, welche auf der Abflussmenge im Vorfluter beruhen, ist die Parametrisierung des Einzugsgebietes minimal. Die Anwendung des RUNOFF-Moduls in einem Testgebiet in der Eifel, Deutschland, deutet darauf hin, dass der Oberflächenabfluss im Grasland empfindlich auf ein kleines Ansteigen der Regenfallintensität und Bodenverdichtung reagiert. Das räumliche Muster der Infiltrationskapazität trägt ebenfalls massgeblich zur Nichtlinearität der Testgebietsreaktion auf veränderten Regenfall und hydrologische Bodenparameter bei.

Schlüsselwörter: Risikoeinschätzung, Oberflächenabflussmodellierung, Hänge, Umweltwandel, GIS

Prof. Dr. Nikolaus J. Kuhn, Department of Environmental Sciences, Institute of Geography/Physical Geography and Environmental Change, University of Basel, Klingelbergstrasse 27, CH-4056 Basel, Switzerland.

e-mail: nikolaus.kuhn@unibas.ch

Dr. Honglei Zhu, Clark Labs, Clark University, 950 Main Street, Worcester, Massachusetts 01610-1477, USA.

e-mail: hzhu@clarku.edu

\section{Manuskripteingang/received/manuscrit entré le} 25.9.2007

Annahme zum Druck/accepted for publication/accepté pour l'impression: 29.2.2008 